\title{
Relationship between Cell Growth and Rate of Protoplasmic Streaming
}

\author{
V. Soran and Georgeta Lazăr-Keul \\ Centre for Biological Research, Cluj-Napoca, Rumania
}

Received September 11, 1976

Von Vesque-Püttlingen (1876) was probably the first who noticed that within small root hairs the rate of streaming is very low, but it increases as cell becomes longer and longer. With a certain cell length the rate of streaming begins to be constant in spite of continous elongation of root hairs. Similar observations were made by Jurisič (1925), Pop (1947, 1948), Doi (1950), Iwanami $(1952,1953)$ and Soran (1957).

Pop $(1948,1950,1956,1960,1967)$ considered that the increase of streaming rate in the growing cell may be related to physical strain of cell cytoplasm during its growth. In order to prove this opinion he and his coworkers (Pop 1960, Pop, Soran and Stirban 1965) tried to elucidate the effect of osmotic shock and mechanical strain on living protoplasm and its streaming rate. Slight increases or decreases of the rate of streaming were obtained corresponding to the phases of plasmolysis or the power of the applied mechanical force. However, no sound relation between physical strain of the living cytoplasm and the increase of streaming rate could be established. Other investigations (Pop, Soran, Vintilă and Stirban 1964, Pop and Soran 1965) performed on various root epidermis cells of barley seedling (Hordeum vulgare $\mathrm{L}$.) showed that different kinds (agitation, circulation, rotation) of streaming characterized these cells. The patterns of streaming were obviously changed with the ageing of cells.

The investigations performed till now in this respect are based on streaming rate measurements within cells of various length we tried to measure the increase of streaming rate in growing root hairs, not to establish a relationship between cell length and rate of streaming, but that between the increase of streaming rate and cell growth.

\section{Material and methods}

Our investigations were carried on barley (Hordeum vulgare L.) root hairs. The germination of barley seed took place on filter paper in Petri dishes, at an approximately constant temperature $\left(20-22^{\circ} \mathrm{C}\right)$. The filter paper was daily wetted with tap water having the same temperature.

At the above mentioned temperature and highest constant moisture, the barley root hairs grew rapidly in 4 hours. The elongation of root hairs was measured under microscope (obj. 10 and screw micrometer eyepiece, C. Zeiss Jena) every 20 minutes and lasted for 6 hours. In order to maintain a constant moisture during 
these measurements we used a micromanipulator humid chamber. The measurements began with the smallest protuberance (future root hairs) on the rhizodermis, and were continously performed on the same cell till it reached a constant length. We have measured the growth of 10 root hairs.

The measurements of streaming velocity were separately performed on 153 root hairs of various length. For the measurements we used a stop watch and a standardized eye-piece scale, according to Strugger's method (1949).

In both cases - the measurement of root hairs growth and the increase of streaming rate-the obtained data were appreciated by means of current statistical methods.

\section{Results and discussions}

1. The growth of root hairs: In Fig. 1 the growth of barley root hairs during 6 hours of observations is plotted: on the ordinate the length of root hairs in $\mu \mathrm{m}$; on the abscissa the time in minutes from the beginning of measurements, when the

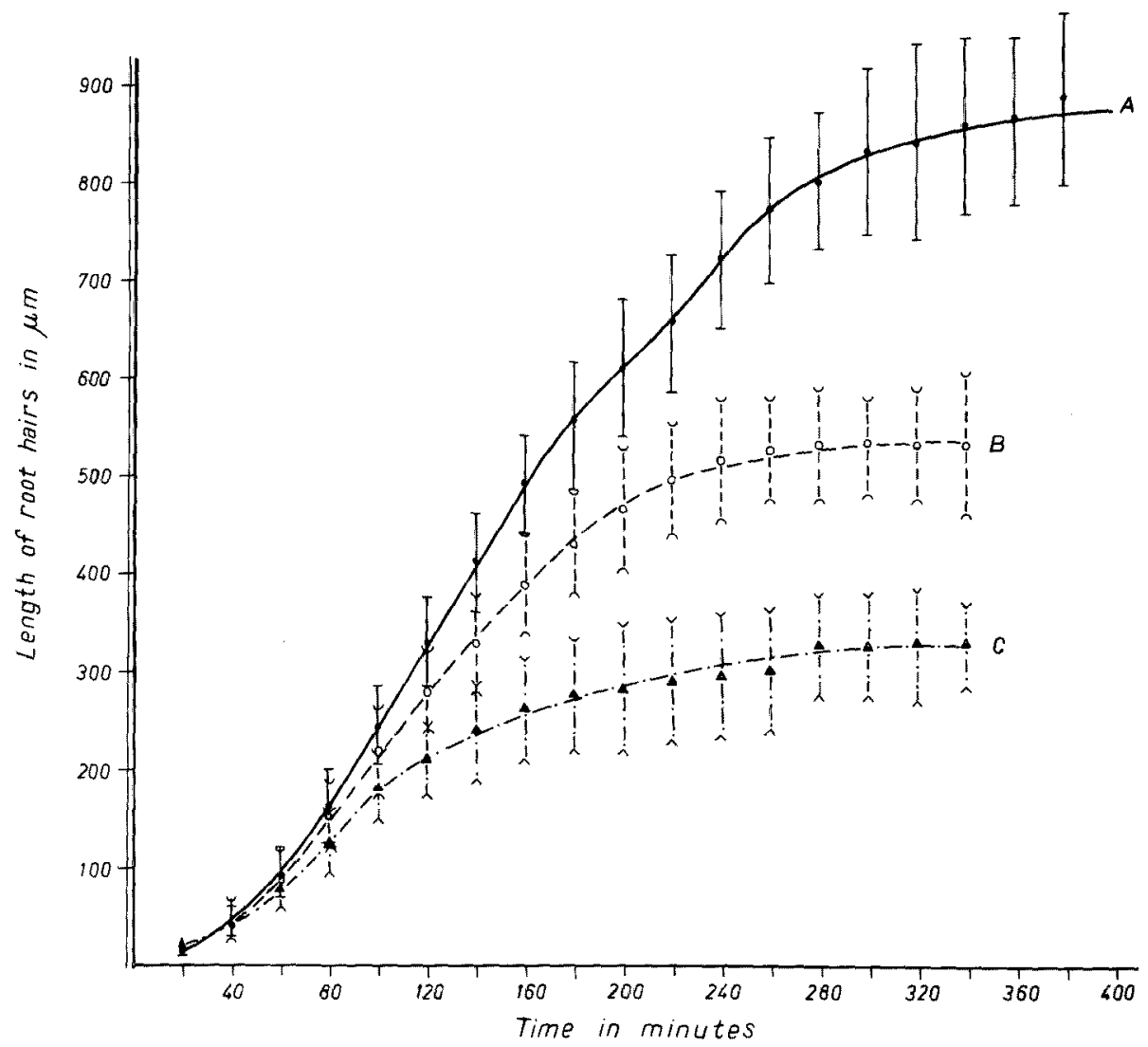

Fig. 1. The growth of barley (Hordeum vulgare $L$.) root hairs in time; $\mathrm{A}=$ root hairs with last length beyond $800 \mu \mathrm{m}, \mathrm{B}=$ root hairs with last length between $500-600 \mu \mathrm{m}, \mathrm{C}=$ root hairs with last length between $300-400 \mu \mathrm{m}$. 
measured root hair had a length near zero. The data allowed us to divide the root hairs into three distinct groups: $A=$ root hairs with a length beyond $800 \mu \mathrm{m}$; $\mathrm{B}=$ root hairs a length between 500 and $600 \mu \mathrm{m}$, and $\mathrm{C}=$ root hairs with a length between 300 and $400 \mu \mathrm{m}$. As shown by standard deviation (Fig. 1) the differences between these three groups of root hairs become obviously significant after 2 or 3 hours from the beginning of their growth.

The growth of root hairs follows the pattern of a logistic function (autocatalithical one) according to the formula:

$$
W=\frac{A}{1+b \cdot e^{-k t}}
$$

where $\quad \mathrm{A}=$ cell length at a given time $\mathrm{t}^{\prime}$

$W=$ cell length after elapsed $t^{\prime \prime}$

$\mathrm{t}=$ time

$\mathrm{k}=$ growth constant

$\mathrm{b}=$ another constant, usually $\mathrm{W}$ value at $\mathrm{t}^{\circ}$

This by many scholars used formula (Evans 1972) allowed us to calculate $k$ value (Table 1) for different root hairs, at a given interval.

Table 1. The constant of growth for three groups of barley root hairs at various intervals of time from the beginning of growth

\begin{tabular}{cccc}
\hline $\begin{array}{c}\text { Elapsed time } \\
\text { from the beginning } \\
\text { of growth }\end{array}$ & A & Group of root hairs & B \\
\hline $2 \mathrm{hr}$ & $3.7 \mu \mathrm{m} / \mathrm{min}$ & $2.8 \mu \mathrm{m} / \mathrm{min}$ & $2.0 \mu \mathrm{m} / \mathrm{min}$ \\
$4 \mathrm{hr}$ & $2.5 \mu \mathrm{m} / \mathrm{min}$ & $0.7 \mu \mathrm{m} / \mathrm{min}$ & $0.6 \mu \mathrm{m} / \mathrm{min}$ \\
$6 \mathrm{hr}$ & $0.8 \mu \mathrm{m} / \mathrm{min}$ & &
\end{tabular}

It was proved that the root hairs with a very rapid growth have a greater rate of growth during the exponential period; it is almost twice greater, than in the root hairs with a slower growth. The rate of growth tends to be approximately equal for all three groups of root hairs towards the end of the process.

In Fig. 2 the pattern of increment for these three groups of root hairs is showed. The increment in all three groups is almost the same, but there are same differences with the optimum term of grand period of growth ( 2 hours for A group, 1 and 3/4 hours for $B$ group, and 1 and $1 / 2$ hours for $C$ group), the moment of maxim increment ( 2 hours and 10 minutes for $\mathrm{A}$ group 1 hour and 50 minutes for $\mathrm{B}$ group and 1 hour and 30 minutes for $C$ group) and value of increment ( $83 \mu \mathrm{m}$ for A group, $65 \mu \mathrm{m}$ for B group and $46 \mu \mathrm{m}$ for $\mathrm{C}$ group). We have not measured the ratio between the length of root hairs and their diameter, but we noticed the usually the longer root hairs are the narrowest. In case of A group, we notice (Fig. 2) several maxima for the growth of root hairs. These oscillations may suggest alternative stimulations and relaxations of their growth, caused probably, by some internal or external factors.

2. The rate of streaming: In Fig. 3 the increase of rotational streaming within A group of root hairs is plotted. It was proved that during the first 3-4 hours, 
when usually the root hairs reached about $800 \mu \mathrm{m}$ in length, the rate of rotational streaming increases constantly.

This increase may be mathematically expressed by so called monomolecular type

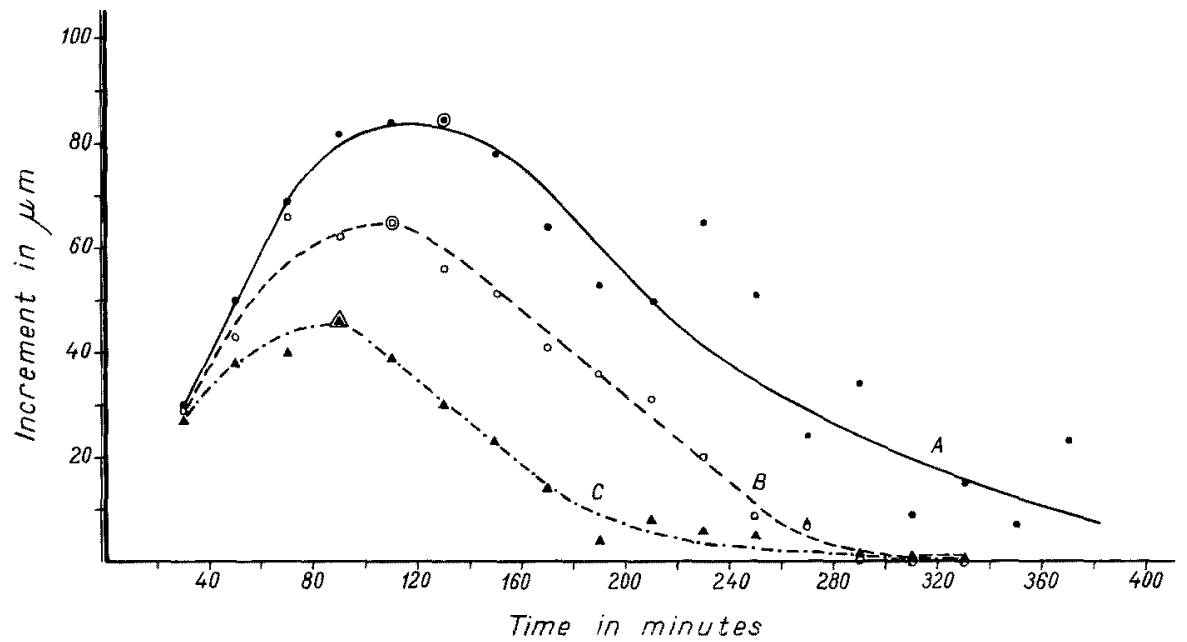

Fig. 2. The increase in three groups $(\mathrm{A}, \mathrm{B}, \mathrm{C})$ of barley (Hordeum vulgare $\mathrm{L}$.) root hairs.

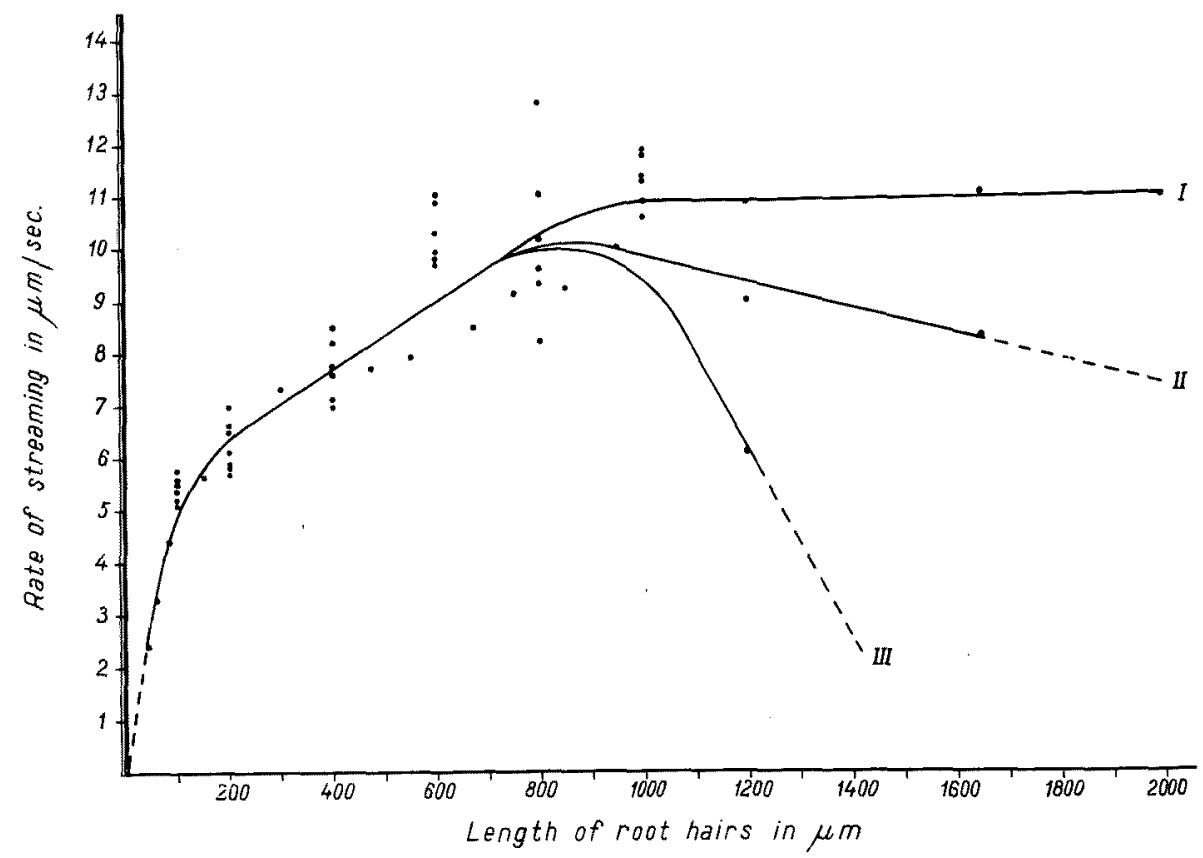

Fig. 3. The relationship between the rate of streaming and the length of barley root hairs. $I=$ root hairs with a length beyond $800 \mu \mathrm{m}$ and constant rate of streaming till the death of cell, II= the slow decrease of streaming rate within root hairs, $\mathrm{III}=$ sudden decrease of streaming rate during the ageing of the root hairs. 
of curve. The curve equation is:

$$
\mathrm{W}=\mathrm{A}\left(1-\mathrm{b} \cdot \mathrm{c}^{-\mathrm{k} t}\right)
$$

and suggests that rotational streaming seems to be the result of a chemical reaction of I-order. If the root hairs are sufficiently long they may be divided into three distinct groups: I, II and III on our diagram. With the first group the rate of streaming remains approximately constant $(11 \mu \mathrm{m} / \mathrm{sec})$ till the death of root hair. In the second group after the rate of streaming reached its maximum $(10 \mu \mathrm{m} / \mathrm{sec})$ it decreased little by little as the growth of root hair stopped. With the third group the lowering of streaming rate is relatively rapid, and followed by a sudden ceasing of any movement. In our opinion these three different behaviours probably correspond to three various kinds of cellular ageing: the slow, the intermediary and the quick one.

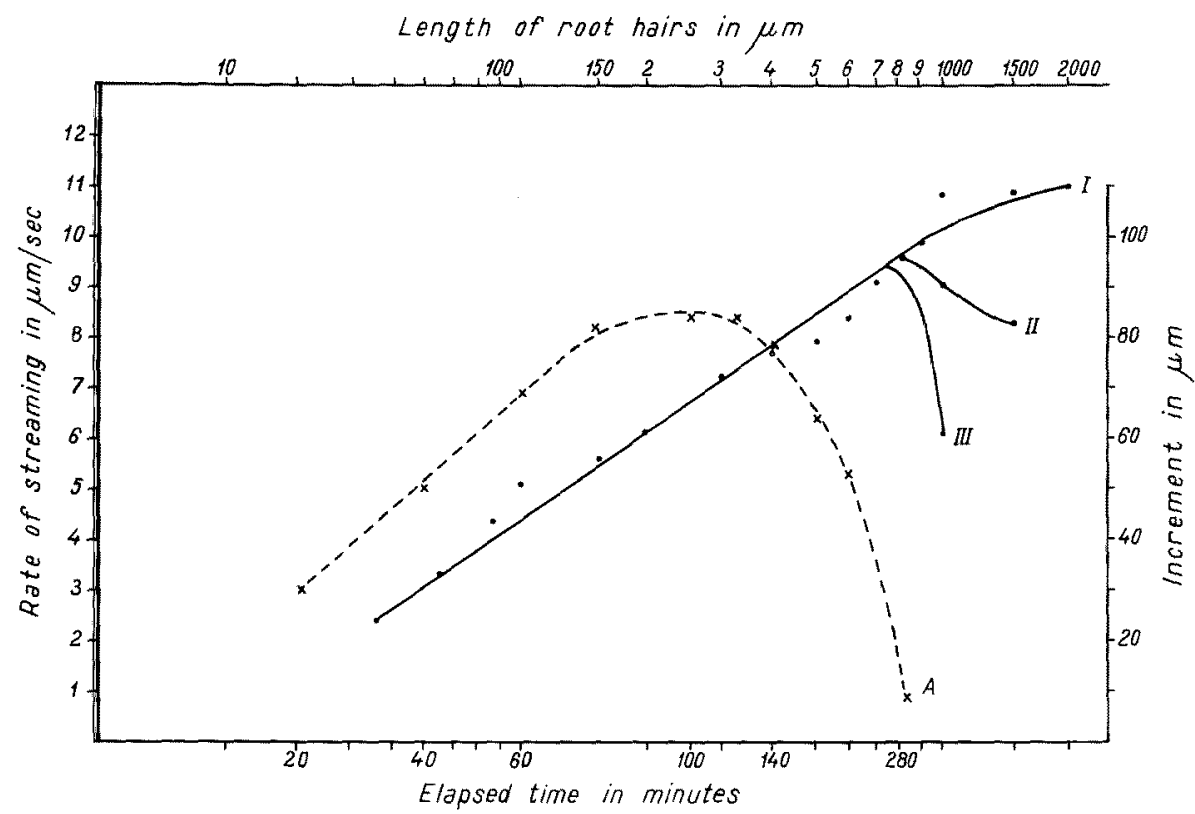

Fig. 4. The correlations between the growth and length of root hairs and the rate of their rotational streaming.

3. Relationship between the rate of streaming and the growth of root hairs: In Fig. 4 both growth of root hairs and the increase of streaming rate at a semilogarithmic scale is plotted.

We calculated the coefficient of correlation between the growth of hairs and the rate of streaming on one hand, and between the length of root hairs and the rate of streaming on the other. It was observed that in the first 80 minutes of growth, when root hairs have grown from 0 to $150 \mu \mathrm{m}$, between the increment, the length of the root hairs and the increase of streaming rate the correlations are positive $(r=$ +0.99 or 0.94 ). These correlations are very close and we accordingly suppose that 
in this short interval the growth of root hairs, even if it did not directly cause the stimulation of streaming, it was one of the main factors which influenced the rate of optimum streaming. When the grand period of growth reached its end the coefficient of correlation between the increment of root hairs and the rate of streaming was a negative one $(r=-0.80)$, but it remained positive $(r=+0.84)$ when the length of root hairs and the increase of streaming rate were taken into account (root hairs of $150-800 \mu \mathrm{m})$. These interesting statistical results proved that the two physiological processes: the growth of root hairs and the increase of streaming rate become nearly independent when grand period of growth was finished. In exchange, the sizes of root hairs had a certain part on the stimulation of streaming rate, probably through several biophysical and biochemical changes that took place within ageing cytoplasm.

The coefficients of correlation were near zero at the root hairs beyond $800 \mu \mathrm{m}$ in length and after 4 hours from the beginning of growth. We may assume therefore that in the last periods of the life of root hairs the rate of rotational streaming has no relation with the growth or length of root hairs. All these results allow us to suppose that physical strain of cytoplasm during the growth of the root hairs and even of the entire plant cells are only outward in connection with the stimulation of the streaming rate. The increase of the streaming rate must be sought in the biochemical changes that take place during cellular growth and ageing.

\section{Zusammenfassung}

In vorliegender Arbit wurden die Beziehungen zwischen Wachstumbzw. Länge der Gerste-Wurzelhaare und der Geschwindigkeitszunahme der Protoplasmaströmung untersucht. Während der frühen Wachstumsphase sind die Wachstumsrate der Wurzelhaare und die Zunahme der Strömungsgeschwindigkeit eng miteinander korreliert. Nach Beendigung der großen Periode des Wachstums bestehen keine Beziehungen zwischen Zellwachstum und Strömungsgeschwindigkeit. Die Erklärung für die mit dem Wachstum der Wurzelhaare korrelierte Zunahme der Strömungsgeschwindigkeit muß eher mit den biochemischen Veränderungen während Wachstum und Alterung als in der mechanischen Dehnung des Cytoplasmas gesucht werden.

\section{Summary}

The relationships between the growth and length of barley root hairs and the increase of streaming rate within them were investigated. In the younger period of growth a good correlation between the growth of root hairs and the increase of their streaming rate may be established. After the end of the grand period of growth there is no relation between cell growth and the increase of streaming rate. The increase of streaming rate into the growing root hairs must be sought rather in the biochemical changes taking place during cellular growth and ageing then in the physical strain of cytoplasm which accompanies the growth. 


\section{References}

Doi, Y. 1950. Protoplasmic streaming in root hairs of crop plant (Japanese with English Summary). Nat. Agr. Exper. Station (Tokyo). Bull. 69: 1-47.

Evans, G. C. 1972. The Quantitative Analyse of Plant Growth, ed. Blackwell Scient. Publ. Oxford-Melbourne-London.

Iwanami, J. 1952. Physiological research of pollen I. On the protoplasmic streaming of pollen tube (Japanese). Bot. Mag. (Tokyo) 65: 137-144.

- 1953. Physiological research of pollen II. On the protoplasmic streaming of pollen tube (Japanese). Bot. Mag. (Tokyo) 66: 49-54.

Jurisic, P. J. 1925. Die Geschwindigkeitsänderung der Protoplasmaströmung in den Pflanzenzellen. Acta bot. Inst. bot. Univ. Zagreb $1: 25-31$.

Pop, E. 1948. Les courants protoplasmiques chez les Labies. Genres Lamium et Salvia. Bull. Soc. Sci. Cluj (Roumanie) 10: 52-66.

- 1950. Les courants protoplasmique chez les Labies II. An. Acad. Rep. Pop. Române (Rumanian with French summary) 3: 517-544.

- 1956. Protoplasmaströmungen bei Labiaten III. Rev, biol. (Acad. Roum.) 1(2): 53-69.

- 1960. Recherches experimentales sur le rapport entre les courants protoplasmiques et l'état de tension du cytoplasme. Rev. biol. (Acad. Roum.) 5(4): 265-274.

- 1967. Statistical and experimental investigations on protoplasmic movements within higher plant cells. Bot. Zhurn. (Moscow) (Russion with English Summary) 52(5): 617-628.

- und Soran, V. 1965. Einige matematisch-statistich Betrachtungen über die Beziehung zwischen der Protoplasmabewegung und der Zellenlänge. Rev. Roum. Biol. Bot. 10(5): 383-391.

-, - and Stirban, M. 1965. Some data concerning the effect of mechanical strain on the protoplasmic movement. Rev. Roum. Biol. Bot. 10(6): 469-480.

-, -, Vintilă, R. and Stirban, M. 1964. Statistische Untersuchungen über die Protoplasmabewegung in Rhizodermiszellen verschiedener Größe. Rev. Roum. Biol. Bot. 9: 377-386.

Soran, V. 1957. Investigations on protoplasmic streaming within corn root haris (Rumanian with French Summary). Studii si cercet. biol. Cluj 8: 295-305.

Strugger, S. 1949. Praktikum der Zell und Gewebephysiologie der Pflanzen. Springer Verlag Berlin.

Vesque-Püttlingen, F. von 1876. Notiz über Periodicität der Protoplasmaströmung. Bot. Ztg. 34: $572-575$. 